\title{
Pengalaman Indonesia Menuju Demokrasi Beberapa Catatan Atas Pemilihan Umum Pada Masa Orde Lama, Orde Baru Dan Pasca Orde Baru
}

\section{Sri Hastuti P.}

Abstract
General election is one of indicators where the pillar of democracy is conducted. It is also the
implementation of human rigth, particularly, political right. In more general context, general
election is an implementation of people's souvereignty, particularly in the perspective of
representative democracy. Public participation can be used as a legal test for the
implementation of peoples's souvereignty principle. It is assumed if public participation
increases, this can reflect people's souvereignty. It also reflect the positive response to the use
of people political right.

\section{Pendahuluan}

Pemilu banyak diyakini sebagai sebuah jalan menuju ke arah demokrasi. Walaupun Pemilu itu sendiri juga sering dianggap hanya sebagai sebuah prosedur demokrasi. Banyak pula negara yang menggunakan Pemilu hanya sekedar memenuhi syarat formal untuk dapat disebut sebagai sebuah negara demokrasi, sehingga tatanan aturan Pemilu (electoral law) maupun proses pemilu (electoral process) tidak mencerminkan apa yang sesungguhnya menjadi tujuan demokrasi.
Demokrasi akan menjadi berharga, setidaknya dapat dilihat dari dua aspek. Pertama, para warga negara mempunyai kekuasaan yang nyata untuk menikmati sekumpulan hak-hak sebagai warga negara. Satu hal yang barangkali menjadi penting untuk diperhatikan adalah, jika demokrasi merupakan pemerintahan oleh rakyat, maka warga negara harus mempunyai otonomi atas otoritasnya sebagai warganegara' Diakuinya warga negara sebagai entitas yang penting dalam keseluruhan proses demokrasi akan

'Hak-hak tersebut mencakup hak untuk berpartisipasi demokratis dan memberlakukannya sebagai hak. Disamping itu, dalam konteks demokrasi, David Held menganjurkan adanya prinsip otonomi, dimana para warga negara mempunyai kemampuan untuk melakukan pertimbangan secara sadar diri, melakukan permenungan diri, dan melakukan penentuan diri. Disamping itu, warga negara harus memiliki kebebasan dalam memilih asosiasi mereka dan pilihan mereka merupakan sebuah legitimasi bagi bentuk dan arah politik mereka. Otonomi juga mencakup kemampuan berunding, mempertimbangkan, memilih dan melakukan tindakan yang berbeda dalam wilayah privat maupun publik dengan memperhatikan nilai kebaikan umum. Baca dalam David Held, Demokrasi dan Tatanan Global, Dari Negara Modern Hingga Pemerintahan Kosmopolitan, Penerjemah Damanhuri, (Pustaka Pelajar, Yogyakarta, 2004), hlm. 180, 181 dan 237. 
menjadi kata kunci bagi proses demokrasi. Jika proses demokrasi mengabaikan warga negara beserta segenap hak-hak dan kewajiban yang melekat padanya, maka hal itu dapat dianggap sebagai sebuah pengingkaran terhadap hakekat demokrasi itu sendiri.

Kedua, negara sebagaimana oleh Held (1995) dianggap sebagai suatu badan hukum independen, sebagai suatu institusi-institusi, ${ }^{2}$ harus merelakan untuk tidak bertindak monopolis, otoriter dalam mengatur dan menjalankan proses demokrasi. Ide tersebut barangkali sering dianggap mengarah ke konsep negara liberal, dimana otoritas negara untuk mencampuri masyarakat sipil dibatasi. Namun demikian, prinsip pembatasan negara tidak semata-mata dapat diklaim sebagai konsep negara liberal. Dalam pandangan negara konstitusional, terdapat prinsip konstitusionalisme dimana pembatasan terhadap negara dimaksudkan guna menjamin kebebasan maksimum bagi setiap warga negara. ${ }^{3}$ Dengan demikian; jjka negara akan memainkan peran dalam proses demokrasi, maka negara harus mempunyai pijakan hukum yang memberi batas-batas kewenangannya secara tegas dan jelas. Dengan demikian, proses demokrasi akan terhindar dari despotisme yang sangat merugikan hak-hak warganegara.

Dari dua prinsip di atas, pemilu yang mengandung otoritas negara dan otoritas warganegara, dapat berjalan tanpa mengabaikan prinsip keseimbangan yang dalam bahasa hukum konstitusi sering disebut sebagai keseimbangan atas prinsip konstitusionalisme. ${ }^{4}$

Pemilihan umum merupakan salah satu indikator bekerjanya pilar demokrasi. Pemilu juga merupakan implementasi dari hak asasi manusia, terutama hak politik. Dalam konteks yang lebih general lagi, Pemilu merupakan wujud kedaulatan rakyat, terutama dalam perspektif demokrasi perwakilan. ${ }^{.}$Oleh karena itu, jika pemerintah tidak melaksanakan Pemilu, itu berarti pemerintah tidak dapat mengklaim dirinya sebagai pemerintah yang bekerja atas asas demokrasi. Oleh karena Pemilu juga merupakan wujud dari

${ }^{2} /$ bid, him. 181. Dalam pandangan C.F Strong, negara bukanlah sekedar suatu perkumpulan sebagaimana sekumpulan keluarga atau persatuan organisasi profesi. Negara adalah entitas komunitas politik yang diorganisir secara tepat. Keberadaannya adalah untuk masyarakat, bukan sebaliknya, masyarakat untuk negara. Oleh karena itu, yang membedakan negara dengan bentuk perkumpulan lainnya adalah kepatuhan anggotaanggotanya terhadap hukum yang dibuatnya. Baca C.F Strong, Konstitusi-KonstitusiPolitik Modem, Kajiantentang Sejarah dan Bentuk-BentukKonstitusi Dunia (Modem Political Constitutions: An Introduction To Comparative Study of Their History and Existing Form), diterjemahkan oleh SPATeamwork, (Penerbit Nuansa dan Nusamedia, Bandung, 2004), hlm 6-7.

${ }^{3}$ David Held,Op.Cit, hlm. 61.

${ }^{4}$ Konstitusionalime diartikan sebagai sebuah sistem yang terlembagakan secara efktif, juga mengandung pengaturan dan pembatasan atas tindakan penguasa, sebagaimana pendapat Wiliam G Andrew, yang dikutip Oleh Jimly Asshiddiqie, Konstitusi da Konstitusionalime Indoensia, diterbitkan oleh (Mahkamah Konstitusi RI dan Pusat Studi Hukum Tata Negara Universitas Indonesia, Jakarta, 2004), hlm 21.

${ }^{5}$ Moh. Koesnardi dan Hamaily Ibrahim, Pengantar Hukum Tata Negara Indonesia, (Pusat Studi Hukum Tata Negara Universitas Indonesia, Jakarta, 1988), hal. 328-329, ditegaskan kembali oleh Moh. Mahfud MD, Politik Hukum Dilndonesia, (LP3ES, Jakarta, 1998), hlm.55 
implementasi hak asasi, ketiadaan Pemilu merupakan pelanggaran terhadap hak asasi manusia di bidang politik. Ketiadaan Pemilu dalam sebuah negara juga merupakan wujud pelecehan terhadap kedaulatan rakyat.

Atas dasar pemikiran di atas, Pemilu secara umum mempunyai 3 (tiga) tujuan. Pertama, memungkinkan terjadinya peralihan kekuasaan secara aman dan tertib. Kedua, untuk melaksanakan Kedaulatan Rakyat. Ketiga, untuk melaksanakan hak-hak asasi manusia. ${ }^{6}$ Pergantian kekuasaan melalui pemilu selain akan menjamin peralihan kekuasaan secara aman dan tertib, juga akan menjamin adanya legitimasi yang kuat terhadap pemerintah itu sendiri. Pelaksanaan Pemilu juga merupakan arena dimana rakyat menunjukkan kedaulatannya, sekalipun dalam sistem perwakilan, pemilu menupakan wujud dari pemberian otoritas politik dari warga negara kepada penguasa. Menurut Jhon Locke, otonitas politik diberikan oleh individu-individu kepada pemerintah dengan maksud mengejar tujuantujuan yang diperintah. Jika tujuan-tujuan tersebut gagal dicapai oleh wakil dari yang diperintah, maka di tangan rakyatlah pertimbangan untuk menolak pemerintahan tersebut atau bila perlu, rakyat menetapkan pemerintahannya sendiri. ${ }^{7}$ Maka dari itu, Pemilu harus dilaksanakan dengan asas kebebasan, dimana rakyat bebas menentukan pilihannya, tanpa ada tekanan dari penguasa atau pihak lain yang mempengaruhi pilihannya.

Partisipasi rakyat dalam Pemilu sering dijadikan tolok ukur bagi bekerjanya asas kedaulatan rakyat, dengan asumsi bahwa jika partisipasi rakyat meningkat, maka itu dapat mencerminkan kedaulatan rakyat, juga akan mencerminkan respon yang positif terhadap penggunaan hak politik rakyat. Dalam pandangan Dahl, meningkatnya partisipasi berarti meningkatnya jumlah warga negara yang memperoleh hak-hak politik dan kebebasan. ${ }^{8}$ Dalam perspektif legitimasi, meningkatnya partisipasi rakyat akan berimplikasi pada kuatnya legitimasi pada pemerintahan yang dibentuk.

\section{Dari Pemilu ke Pemilu, Sebuah Retrospeksi}

\section{a. Pemilu 1955}

Pemilihan Umum tahun 1955 memperoleh dasar yuridis konstitusional melalui Pasal 1 ayat (2), Pasal 35 dan Pasal 57 UUDS $1950 .^{\circ}$

${ }^{6}$ Moh. Koesnardi dan Harmaily lbrahim, lbid, him 330

${ }^{7}$ Ajaran Jhon Locke berintikan pada kekuasaan yang tertinggi merupakan hak yang tidak bisa dipisahkan dari rakyat. Bahwa supremasi pemerintah adalah supremasi yang didelegasikan.(dari rakyat-add penulis). Pemerintah dapat menikmati otoritas politikjuga sepanjang ia memperoleh kepercayaan (dari rakyat-add penulis). Pendapat Jhon Locke, sebagaimana diuraikan kembali oleh David Held, dalam Demokrasi dan Tatanan Global...,op.cit., hlm. 51-52

${ }^{8}$ Pendapat Dahl, sebagaimana dikutip oleh Georg Sorensen, Demokrasi dan Demokratisasi: Proses dan Prospek dalam Dunia Yang sedang Berubah (Democracy and Democratization: Process and Prospects in a changing Worl), penerjemah I. Made Krisna, (Pustaka Pelajar, Jogjakarta, 2003), hal 20-21. Partisipasi merupakan salah satu kondisiyang harus dipenuhi untukmenciptakan demokrasi poltik, selain tingkat kompetisidan kebebasan politikdan sipil. Oleh karena itu, sebuah rezim yang nondemokratis, dapat saja menjauhkan warganegaranya dari partisipasi.

${ }^{9}$ UUDS merupakan Undang-Undang Dasar yang berasal dari Konstitusi RIS 1949, berlaku sebagai UUD RI berdasarkan UU No. 7 Tahun 1950. Bunyi Pasal 1 ayat (2) adalah:" Kedaulatan Republik Indonesia 
Pemilihan umum Tahun 1955 di Indonesia sering dijjadikan rujukan untuk proses pemilu dengan sistem multi partai. Pemilihan umum Tahun 1955 merupakan Pemilu Nasional pertama yang diselenggarakan secara aman dan damai. ${ }^{10}$ Perserta Pemilu 955 selain partai politik juga perorangan, walaupun untuk yang terakhir (calon perorangan) tidak ada satupun yang berhasil dalam kedua pemilihan (pemilihan anggota DPR dan Pemilihan Badan Konstituante). ${ }^{11}$

Sebagaimana Pemilu 2004, Partai Politik peserta pemilu pada Pemilu 1955 juga mencantumkan nama calon legislatifnya, sesuai dengan ketentuan UU No 7 Tahun 1953 tentang Pemilihan anggota Konstituante dan anggota DPR. Sistem Pemilu yang digunakan dalam Pemilu 1955 adalah proporsional terbuka. Hal itu dapat dilihat dari ketentuan Pasal 15 UU No. 7 Tahun 1953 ayat (1) mengenai daerah pemilihan sejumlah 16 (enam belas) daerah pemilihan dimana pada ayat (2) nya ditentukan bahwa masing-masing daerah pemilihan tersebut akan dipilih anggota Konstituante dan anggota DPR yang jumlahnya seimbang dengan jumlah penduduknya. Sifat terbuka dapat dilihat dari mekanisme pemilihannya, sebagaimana dijelaskan dalam Pasal 67 adalah Pemilih memberikan suara kepada suatu daftar dengan menusuk tanda gambar daftar itu dan untuk perseorangan, pemilih memberikan suara kepada seorang calon dengan menulis nomor daftar serta nama calon. (Pasal 67 ayat (2) UU No 7 Tahun 1953).

Salah satu syarat untuk menyelenggarakan Pemilu secara demokratis adalah adanya komite Pemilihan (semacam Panitia Pemilihan) yang independen sifatnya. Pemilu 1955 dilaksanakan oleh sebuah lembaga bernama Panitia Pemilihan. Panitia Pemilihan yang terdapat di lbu Kota Negara, ditunjuk oleh Presiden dengan nama Panitia Pemilihan Indonesia. Di tiap-tiap daerah pemilihan terdapat juga panitia pemilihan yang ditunjuk oleh Menteri Kehakiman dengan nama Panitia Pemilihan, di tiap Kabupaten panitia pemilihan ditunjuk oleh Menteri Dalam Negeri dengan

adalah di tangan rakyat dan dilakukan oleh Pemerintah bersama-sama dengan Dewan Perwakilan Rakyat". Bunyi Pasal 35:"Kemauan Rakyat adalah kekuasaan penguasa; kemauan itu dinjatakan dalam pemilhan berkala jang djudjur dan dilakukan menurut hak pilh bersifat umum dan kebersamaan, serta dengan pemungutan suara jang rahasia ataupun menurut tjara jang djuga mendjamin kebebasan mengeluarkan suara". Lalu bunyi Pasal 57 adalah:" Anggauta-anggauta Dewan Perwakilan Rakjat dipilih dalam suatu pemilihan oleh warga negara Indonesia jang memenuhi sjarat-sjarat dan menurut aturan-aturan jang ditetapkan dengan undang-undang".

${ }^{10}$ Kurang lebih ada 29 Partai Politik yang mendapatkan suara dalam Pemilu 1955. Meskipun banyak partai tetapi pelaksanaan Pemilu cukup aman dan damai. Menurut Herbert Feith, salah satu kunciberlangsungnya Pemilu 1955 secara demokratis dan relatif aman dan damai adalah diwakilinya semua partai dalam badan penyelenggara (sebagimana dituturkan oleh Herbert Feith dalam wawancaranya dengan wartawan Tabloid Detik, Najib Asca, pada bulan Februari 1999). Baca lebih lanjut dalam Herbert Feith, Pemilhhan Umum $1955 \mathrm{di}$ Indonesia, KPG, Jakarta, 1999, hlm. x

$" \mathrm{lbid}$, hal 91 . Suara perorangan dapat menjadi besar apabila ada penggabunga suara dalam satu daerah pemilihan dan penggabungan suara perorangan ini dimungkinkan karena dalam UU No. 7 Tahun 1953, pada Pasal 37 ada ketentuan tentang penggabungan suara perorangan. Lihat UU No. 7 Tahun 1953 tentang pemilihan anggota Konstituante dan anggota DPR. 
nama Panitia Pemilhan Kabupaten. Sementara itu. Di tiap kecamatan terdapat Panitia Pemungutan Suara dan di tiap desa terdapat Panitia Pendaftar Pemilih. ${ }^{12}$ Walaupun otoritas penunjukkan ketua dan anggota panitia pemilih ada di tangan eksekutif (Presiden, Menteri Kehakiman dan Menteri Dalam Negeri), namun pada praktiknya panitia pemilih dapat bekerja secara independen, setidaknya independen ini dapat dipahami bahwa panitia pemilih tidak terbawa pada keharusan memenangkan partai pemerintah yang berkuasa, meskipun keberadaan mereka atas penunjukan Presiden dan para menterinya. Satu hal lagi yang perlu dicatat pada Pemilu 1955 ini adalah masalah pendaftaran pemilih. Pendaftaran Pemilih dilakukan oleh panitia pendaftar pemilih yang ada di tingkat desa dan setelah dilakukan pendaftaran, maka panitia pendaftaran pemilih harus mengumumkan kepada masyarakat selama 30 hari. Jika masih ada warga yang belum terdaftar, maka waktu 30 hari tersebut dipandang cukup untuk mendapat pendaftar tambahan. Selain itu, dalam pendaftaran, jika pemilih mempunyai tempat tinggal lebih dari satu, maka, pemilih ketika didaftar harus menentukan salah satu tempat tinggalnya dimana dia akan menggunakan hak pilihnya. Mekanisme pendaftaran oleh panitia pendaftaran pemilih tingkat desa/kelurahan yang memberikan tenggang waktu kepada masyarakat untuk melihat daftar pemilih ini cukup baik untuk menghindari adanya warga yang telah memenuhi syarat sebagai pemilih tetapi tidak terdaftar sebagai pemilih. Selain itu, ketentuan UU yang menentukan bahwa pemilih yang mempunyai tempat tinggal lebih dari satu, harus menentukan salah satu tempat tinggalnya juga baik untuk menghindari adanya pendaftar double dan juga untuk menghindari adanya kemungkinan kecurangan yang dilakukan oleh pemitih dengan memilih di dua tempat.

Ditinjau dari segi tingkat partisipasi warga, Pemilu 1955 untuk memilih anggota Dewan Perwakilan Rakyat pada tanggal 29 September 1955 dilikuti oleh lebih dari 39 juta rakyat Indonesia dan kurang lebih $91,54 \%$ yang memberikan suara. $2,5 \%$ meninggal pada masa antara pendaftaran hingga menjelang pemilihan. Praktis, hanya $6 \%$ dari warga negara Indonesia yang terdaftar tidak menggunakan hak mereka. Diantara yang terdaftar, $87,65 \%$ suara dinyatakan sah. Kemudian untuk pemilhan anggota badan Konstituante yang berlangsung bulan Desember, tingkat partisipasi warga negara juga tinggi, kurang lebih $90 \%$ warga yang menggunakan hak pilihnya. ${ }^{13}$ Tingkat partisipasi warga negara yang tinggi ini menunjukkan bahwa ada semangat yang begitu tinggi bagi masyarakat untuk membangun demokrasi melalui Pemilihan Umum. Namun begitu, Pemilu 1955 tidak terlepas dari hal yang negatif. Adnan Buyung Nasution mencatat, bahwa kampanye besarbesar yang sudah dimulai pada tahun 1953 hingga menjelang Pemilu, menimbulkan gelombang yang saling bertentangan. Pertentangan itu berembrio pada pidato Soekamo di Amuntai (Kalimantan) yang terang. terangan menentang berdirinya negara RI yang berasaskan Islam. ${ }^{14}$ Meskipun secara garis

\footnotetext{
${ }^{12}$ Baca lebih lanjut Pasal 17 UU No 7 Tahun 1953.

${ }^{13}$ Herbert Feith, Op. Cit., him 57.

${ }^{14}$ Adnan Buyung Nasution, Aspirasi Pemerintahan Konstitusional di Indonesia: Studi Sosio Legal atas
} 
besar Pemilu 1955 berjalan dengan baik, tetapi juga tidak terlepas dari adanya tindakan yang kurang demokratis yang dilakukan oleh partai politik tertentu melalui oknum-oknumnya, seperti tindakan tekanan dari Masyumi pada pemilih diberbagai tempat di Aceh dan Jawa Barat, dan intimidasi yang dilakukan oleh Lurah-Lurah PNI dan para pembantunya di Jawa tengah dan Jawa Timur. ${ }^{15}$

Pada akhirnya, ada pemakluman terhadap sisi negatif dari Pemilu 1955, sebab Pamilu 1955 merupakan Pemilu Nasional pertama bagi bangsa Indonesia. Sebagai sebuah langkah awal untuk membentuk pemerintahan yang demokratis, Pemilu 1955 menjadi preseden baik bagi tumbuhnya semangat berdemokrasi untuk Indonesia.

\section{b. Pemilu Orde Baru.}

Orde Baru sebagai sebuah istilah yang melekat pada rezim yang menggantikan Soekarno mempunyai keinginan yang kuat untuk mencoba tampil beda dari rezim Orde Lama, yang sejak 1959 telah memulai menunjukkan otoriternya secara kentara. Sejumlah rekayasa dibuat oleh Rezim Orde
Baru, diantaranya yang terpenting menurut Mohtar Mas'oed (1989) dalam melalui rekayasa politik tahun 1969 dimana ada penggabungan ratusan kelompok fungsional yang berbeda-beda, termasuk pegawai negeri yang ditransformasikan ke dalam parati Golkar. ${ }^{16}$ Namun demikian, Orde Baru bukanlah antitesis dari orde lama. Dalam hal sistem dan kebijakan politik yang cenderung otoriter dan monopolistik, Orde Baru adalah penerus dari Orde Lama. Tujuan politik Orde Baru adalah menciptakan stabilitas politik dan pembangunan ekonomi dengan memberlakukan mekanisme politik yang tidak memungkinkan adanya koreksi. Format politiknya cenderung kurang menyantuni rakyat dan banyak melanggar hal-hal yang ideal dari republik ini. ${ }^{17} \mathrm{Hal}$-hal lain yang menjadi ciri khas orde baru adalah tingkah laku partai dan lembaga perwakilan pada masa orde baru yang mendukung status quo sistem politik. Organisasi politik dan parlemen sangat loyal kepada Presiden Soeharto, terdapat "penggusuran" kader politik yang vokal dari posisi di partai politik maupun di DPR dan lembaga politik cenderung memberikan

Konstituante 1956-1959, Cet. Kedua, (Grafiti, Jakarta, 2001), hlm 30. Pidato Soekarno tersebut menyulut protes tokoh-tokoh partai Islam, seperti Isa Anshary dari Masyumi.

${ }^{15}$ Herbert Feith,Op.Cit., hlm 68-69. Bukti-bukti andanya intimidasi berasala dari laporan Pemilu. Disejumlah Desa di Jawa, Lurah mengancam pemilih dengan hukuman penjara dan denda yang besar kalau tidak memilih PNI, di Desa lain berupa ancaman penghentian pasokan garam dan kebutuhan lain, ancaman disuruh meninggalkan desa jika tidak mengikuti petunjuk lurah mengenai pemungutan suara. Partai Komunis melalu. pemuda-pemuda Komunis dan oknum-oknumnya juga mengintimidasi dari rumah ke rumah untuk mengumpulkan tanda tangan dan cap ibujar keanggotaan organsiasi-organisasi front Komunis dan mengancam serta menculik penduduk yang tidak mau memilih partai yang bergambar Palu Arit.

${ }^{16}$ Mohtar Mas'oed, Ekonomi dan Struktur Politik. Orde Baru 1966-1971, LP3ES, 1989, sebagaimana dikutip oleh Mochtar Pabottinggi, Delima Legitimasi Orde Ban;; Bayangan Krisis Politik dan Arah Pemecahannya, dalam Syamsudin Haris dan Reza Sihbudi (ed), Menelaah Kembali Format Politik Orde Baru, (Gramedia, Jakarta, 1995), hlm 25-26.

${ }^{17}$ Mochtar Pabottinggi, lbid., hlm 26, 32 
perhatian pada kepentingan jangka pendek dibandingkan kebutuhan jangka panjangnya sendiri. ${ }^{18}$ Selain itu, Orde Baru juga melahirkan kekuatan politik yang pada masa perjalanannya menjadi sangat kuat dan solid, yaitu $A B R I$, terutama Angkatan darat. ${ }^{19}$ Orde Baru juga berupaya menguatkan negara untuk dapat mengatasi berbagai konflik dengan tiga strategi. Pertama, menempatkan kekuatan pemerintahan di DPR secara dominan. Kedua, Penyederhanan sistem kepartaian. Ketiga, menetapkan Pancasila sebagai satusatunya azas. Komposisi DPR dibuat sedemikian rupa agar tidak menyebabkan disintegrasi. Organisasi politik, terutama parati politik, dilakukan penataan karena pada masa orde lama, gangguan integrasi nasional banyak dilatarbelakangi oleh bervariasinya organisasi politik yang mewadahi berbagai kepentingan primordial dan saling memperebutkan dominasi. ${ }^{20}$

Sebenarnya Orde baru lebih memilih membangun ekonomi ketimbang politik, karena ekonomi yang kuat dan mapan, akan menjauhkan Indonesia dari kemiskinan dan keterbelakangan, dan implikasi lebih jauh dari kemapanan ekonomi adalah dapat mengeiliminir bahaya komunisme yang akan tumbuh subur- menurut asumsi Orde Baru jika perut rakyat itu lapar. Namun demikian, pembangunan ekonomi Orde Baru dibarengi dengan penciptaan stabilitas dengan pendekatan kemanan yang ketat. ${ }^{21}$ Oleh karena itu, tidaklah mengherankan apabila perjalanan Orde Baru meninggalkan sejumlah sejarah hitam yang bagi sebagian masyarakat Indonesia, merupakan penindasan yang sangat sistematis.

Terobsesinya Orde Baru untuk membangun ekonomi yang kuat atas dasar pembangunan yang menitik beratkan pada ekonomi membawa rezim ini mengambil sikap tertentu dalam hal Pemilu. Pemilu harus dilaksanakan sesuai dengan tuntutan konstitusi, namun kekuatan pemerintah harus mendapat jaminan untuk memenangkan Pemilu. Hal itu dimaksudkan agar pemerintah dapat mendominasi lembaga permusyawaratan

${ }^{18}$ Arbi Sanit, Sistem Kepartaian dan Perwakilan Orde Baru:Masalah dan Prospeknya, dalam dalam Syamsudin Haris dan Reza Sihbudi (ed), Menelaah Kembali Format Politik Orde Banu, (Gramedia, Jakarta, 1995), him $39-40$

"9Juwono Sudarsono dalam "integrasi, Demokrasi, dan Pembauran Politik" artikel Kompas, 2 Desember 1987, sebagaimana dikutip oleh Moh. Mahfud MD, Demokrasi dan Konstitusid Indonesia, (Liberty, Yogyakarta, 1993), hlm. 76

${ }^{20}$ Moh. Mahfud MD, Ibid, him 76,77.

21Untukmenciptakan stabilitas nasional, Orde Barumembentuklembaga-lembaga yang mempunyaikekuatan represif seperti Opsus, Kopkamtib/Laksus, Dirjen Sosopol atau Ditsospol di Depdagri. Orde Baru juga memberi "rewards" yang sebaik-baiknya kepada lembaga, kelompok, dan individuyang memperlihatkan sikap akomodatif terhadap Orde Baru. Baca dalam Afan Gaffar, Politik Indonesia ; Transisi Menuju demokrasi, Cet. Kedua, (Pustaka Pelajar, 2000), hlm. 148-149. Sebaliknya, lembaga-lembaga, kelompok, individu-individu yang tidak akomodatif, bahkan cenderung kritis terhadap kebijakan-kebijakan penguasa Orde Baru, mendapat perlakuan yang represif. Sebagai Contoh apa yang menimpa Hariman Siregar, Arief Budiman, Sri Bintang Pamungkas adalah bagian dari catatan sejarah yang menunjukkan tindakan represif penguasa Orde Baru kepada mereka yang dianggap "mengganggu" stabilitas nasiona. 
lembaga perwakilan guna membangun negara dalam situasi politik yang stabil.22

Orde Baru mempunyai beberapa karakteristik. Pertama, lembaga Kepresidenan yang terlampau dominan. Lembaga ini hampir tidak mempunyai tandingan, terutama dalam membentuk format politik, karena sumber daya politik yang diperlukan dalam proses politik, sangat besar dalam lembaga ini. Lembaga ini bahkan sampai dapat mengontrol rekrutmen politik, baik yang ada di lembaga-lembaga tinggi negara, birokrasi, bahkan pada partai politik, organisasi masyarakat dan organisasi ekonomi. Khusus pada rekrutmen di partai politik, Orde Baru menerapkan cara dimana pemimpin partai politik yang kritis, apalagi mengambil oposisi/ menentang pemeritah, tidak akan memimpin partai politik. Hanya mereka yang akomodatif dengan pemerintah saja yang diberi jalan untuk memimpin partai politik. Kedua, rendahnya kesetaraan di antara lembagalembaga negara. Ketiga, rekruitmen politik yang tertutup. Keempat, birokrasi sebagai instrumen kekuasaan. Kelima, kebijakan publik yang tidak transparan. Keenam, sentralisasi. Ketujuh, implementasi HAM yang masih rendah. Kedelapan, Sistem Peradilan yang tidak independen. ${ }^{23}$
Pemilu selama Orde Baru berlangsung enam kali $(1971,1977,1982,1987,1992$, 1997). Penyelenggaraan Pemilu selama Orde Baru menggunakan dasar hukum yang berbeda-beda. Untuk Pemilu tahun 1971, dasar hukumnya adalah UU No 15 Tahun 1969 tentang Pemilihan Anggota-anggota Badan Permusyawaratan/Perwakilan Rakyat, Pemilu tahun 1977 berdasarkan UU No 4 Tahun 1975 tentang Perubahan atas UU NO 15 Tahun 1969, dan tahun 1982 menggunakan UU No 2 Tahun 1980 tentang Perubahan atas UU No 15 Tahun 1969 sebagaimana telah di rubah dengan UU No 4 Tahun 1975. Untuk Pemilu tahun 1987, 1992 dan 1997 menggunakan UU No 1 Tahun 1985.

Meskipun di bawah aturan yang berbeda, namun secara umum UU Pemilu yang berlaku selama Pemilu Orde Baru mencerminkan karakter produk hukum yang ortodoks/elitis/ konservatif. Karakter produk hukum ini isinya lebih mencerminkan visi politik elit politik, lebih mencerminkan keinginan pemerintah dan bersifat positivis-instrumentalis. ${ }^{24} \mathrm{Hasil}$ Pemilu Orde Baru secara umum juga telah menghasilkan pola perimbangan antar kekuatan politik yang khas dan terjaga, dimana Golkar selalu menjadi pemenang Pemilu dengan perolehan suara mutak (di atas $50 \%$ ).

${ }^{2}$ Moh. Mahfud MD, Politik Hukum di Indonesia, (LP3ES, Jakarta, 1998), him 322 Baca juga hlm 25 yang menguraikan karakter produk hukum.

${ }^{23}$ Afan Gaffar, Ibid, hlm 150. Contoh nyata dari tindakan penguasa Orde Baruyang sangat tidak demokratıs dalam rekrutmen pemimpin partai politik adalah dalam soal penentuan pimpinan Partai Demokrasi Indonesia. Soerjadi, yang dianggap akomodatif dengan penguasa Orde Baru terpilih sebagai Ketua PD!, walaupun dalam Munaslub di Surabaya, Mayorites konstituen partai tersebut lebih memilih Megawati, yang pada waktu itu dianggap kurang/tidak akomodatif terhadap penguasa Orde Baru. Dukungan Pemerintah terhadap Soerjadi menjadikan massa pendukung Megawati menjadi progresif. Akhimya Partai terbelah menjadi dua, ada PDI pro Soerjadi dan PDI Pro Mega yang berpuncak pada terjadinya penyerbuan kantor PDI di jalan Diponegoro No 58, Jakarta Pusat, yang terkenal dengan insiden 27 Juli 1996.

${ }^{24} \mathrm{Ibid}, \mathrm{hlm} 323$ 
Tahun 1971, Golkar meraih $62,56 \%$ suara pemilih dan menguasai kursi DPR 65,56 \%. Pada Pemilu tahun 1977, suara yang didapatkan Golkar adalah $62,11 \%$ dan menguasai kursi di DPR 64,44. Pemilu tahun 1882 , suara yang diperoleh Golkar adalah $64,34 \%$ dan mendapatkan kursi DPR 60,50 $\%$. Pada Pemilu 1987, suara yang didapat Golkar adalah $73,16 \%$ dan mendapatkan kursi DPR 74,75. Pada Pemilu 1992, Golkar meraih $68,10 \%$ suara dan mendapat jatah kursi DPR $70,50 \%$. Kemenangan Golkar ini menimbulkan tanda tanya besar, kenapa bisa dalam setiap Pemilu, Golkar selalu mengantongi peringkat pertama. Ada sinyalemen bahwa kemenangan tersebut diraih dengan cara-cara yang tidak elegan dan tidak sehat (tidak jujur dan adiltambahan penulis). Pemilu orde baru juga menunjukkan tingkat partisipasi masyarakat yang tinggi untuk menggunakan hak pilihnya. ${ }^{25}$ Tingkat partisipasi masyarakat dalam menggunakan hak pilhnya memang menjadi preseden yang baik bagi terciptanya iklim demokrasi politik di Indonesia. Namun demikian, partisipasi warga yang benar-benar berimplikasi positif pada demokrasi politik adalah partisiapsi yang meluas, tanpa diskriminasi penggunaan hak pilih, dan ada kebebasan untuk menentukan pilihannya. Jika meningkatnya partisipasi warga karena ada mobilisasi, intimidasi dan dibawah bayangbayang ketakutan akan adanya ancaman dari rezim yang berkuasa, maka tingkat partisipasi ini hanya merupakan kamuflase belaka, yang dapat menjungkirbalikkan tujuan

Pemilu tahun 1997 juga tidak terlepas dari berbagai kritikan, Hasil penelitian CIDES menyimpulkan bahwa Pemilu tersebut tidak demokratis ${ }^{26}$. Lagi-lagi Golkar juga masih memegang peringkat pertama perolehan suara. Tingkat partisipasi masyarakat dalam menggunakan hak pilihnya memang menjadi preseden yang baik bagi terciptanya iklim demokrasi politik di Indonesia.

Sistem proporsional yang diterapkan tanpa adanya daftar calon legislatif menjadikan partai demikian besar dalam menentukan wakil-wakilnya. Sehingga, otoritas si wakil lebih banyak tergantung kepada partainya. Sistem yang demikian memang diinginkan oleh rezim kekuasaan pada saat itu dan dilegalisasi melalui undang. undang Pemilunya.

Sistem proporsional yang diterapkan pada Pemilu orde baru memang mengandung sejumlah kelemahan. Pertama, dari segi asas keterwakilan, wakil-wakil yang dicalonkan oleh partai tidak terikat oleh ketentuan domisili. Dengan demikian, sangat mungkin seorang wakil rakyat mewakili daerah yang bukan tempat asal ataupun tempat domisilinya. Kedua, dari segi hubungan antara si wakil dengan konstituennya, sistem proporsional Pemilu orde baru melahirkan hubungan yang renggang antara rakyat dan wakilnya. Hal ini terjadi karena hubungan antara si wakil

${ }^{25}$ Eep Saifullah Fatah, Pemilu dan Demokratisasi, Evaluasi terhadap Pemilu-Pemilu Orde Baru, Laboratorium FISIP UI dan (Mizan, Jakarta - Bandung, 1997), hlm 19-20.Tingkat partisispasi yang tinggi dalam Pemilu Orde Baru juga dilakukan dengan mobilisasi politik kepada pemilih dan pada waktu itu ada stigma bahwa warga negara yang tidak menggunakan hak pilihnya, dianggap warga yang "abnormal"

${ }^{25}$ Indria Samego, dkk (ed) Dinamika Kedaulatan Rakyat; Dilema-Dilema dalam Pemilu, Sistem Kepartaian dan Lembaga Perwakilan, (Pustaka Cidesindo, Jakarta, 1997), hlm 66-67. 
dengan konstituennya hanya melalui partai. Dengan demikian, rakyat tidak mempunyai akses secara langsung untuk mengontrol wakilnya. Ketiga, Proporsional yang berbasis wilayah, pada kenyataannya di Indonesia melahirkan kesenjangan antar kawasan. Komposisi DPR didominasi oleh mereka yang berasal daerah yang padat penduduknya, sehingga kebijakan pembangunan sepertinya lebih banyak terarah pada daerah-daerah tertentu.

Selain itu, dari sudut sistem kepartaian, Pemilu orde baru memang menunjukkan kestabilan politik. Dengan kebijakan tiga partai, maka akan lebih mudah bagi partai yang menang dalam Pemilu untuk memobilisasi massa dalam Pemilu-Pemilu berikutnya. Namun kesetabilan tersebut menjadi tidak berarti apabila hak politik rakyat dibendung, karena dalam perjalannnya partai-partai politik yang ada sudah tidak lagi sejalan dengan aspirasi masyarakat. Partai-partai yang ada hanya mempertahankan status quo saja. Dengan demikian, apalah artinya sistem partai yang terbatas jika partai-partai yang ada itu tidak lagi dapat menyalurkan aspirasi masyarakat..

Dari segi teknis pelaksanaan, sebuah jajak pendapat mengenai Pemilu-Pemilu Orde baru, mengindikasikan beberapa kelemahan. Petama, ada campur tangan birokrasi dalam mempengaruhi pilihan masyarakat. Kedua, Penitia Pemilu tidak independen, memihak salah satu kontestan. Ketiga, Kompetisi antar kontestan tidak leluasa. Keempat, Rakyat tidak bebas mendiskusikan dan menentukan pilihannya.
Kelima, penghitungan suara tidak jujur. Keenam, tidak semua kontestan bebas berkampanye. ${ }^{27}$ Kelemahan-kelemahan tersebut patut dipelajari guna perbaikan penyelenggaraan Pemilu di Indonesia pada masa yang akan datang.

Pemilu Orde Baru memang banyak melahirkan kritik atas penyelenggaraannya. Pemilu Orde Baru belum memberikan kesadaran kolektif terhadap rakyat mengenai pentingnya hak-hak politik rakyat. Kritik yang diberikan oleh William Liddle melalui penelitian kualitatifnya terhadap PemiluPemilu Orde Baru adalah Pemilu belum memadai sebagai alat untuk mengukur suara rakyat, sebab Pemilu-Pemilu Orde Baru dilaksanakan melalui sebuah proses yang tersentralisasi pada tangan-tangan birokrasi yang mana tangan-tangan tersebut tidak hanya mengatur hampir seluruh proses Pemilu, tetapi juga berkepentingan untuk merekayasa kemenangan "partai milik pemerintah". Kompetisi ditekan sedemikan rupa dan keragaman pandangan tidak memperoleh empat secara memadai. ${ }^{28}$

Pemilu Orde Baru memang berjalan secara reguler. Dan dalam perspektif demkorasi, sebuah regularitas pemilu memang menjadi syarat formal sebuah negara demokrasi. Namun demikian, regularitas Pemilu belum tentu dapat menjamin tegaknya sebuah negara demokrasi. Jika regularitas itu hanya untuk memenuhi ritual politik, maka, Pemilu tersebut telah kehilangan "ruh" yang sebenarnya, sebab hanya sekedar rutinitas yang hasilnya tidak akan membawa perubahan pada tataran

${ }^{27}$ lbidhal 21-22

${ }^{29}$ Baca dalam Eep Saifullah Fatah, Op.Cit, hal 21 juga dapat ditemukan dalam tulisan Indria Samego. dkk (ed), Dinamika Kedaulatan Rakya......,Op.Cit. 
sistem politik. Hikam mengatakan, apapun hasilnya, Pemilu Orde Baru tidak ditujukan untuk mengubah sistem politik, melainkan hanya untuk meneguhkan dan mengabsahkan sistem yang berlaku. Dalam hal pencalonan Presiden, berapa kali Pemilu Orde Baru, Golkar dan Partai-Partai di luar Golkar selalu mencalonkan Soeharto sebagai Presiden. Oleh karena itu Pemilu di Indoensia (pada masa Orde Baru) lebih diberi bobot sebagai sebuah kewajiban ketimbang hak warga negara. ${ }^{29}$

\section{c. Pemilu Pasca Orde Baru.}

Reformasi ternyata melahirkan beberapa perubahan, termasuk dalam soal penyelenggaraan Pemilu 1999. Sistem multi partai Pemilu 1999, yang diatur dalam UU No 2 Tahun 1999 tentang Partai Politik, ternyata benar-benar memberi kesempatan kepada masyarakat Indonesia - yang sebelumnya terbelenggu aspirasi politiknya - untuk membentuk partai politik seseuai dengan aspirasi yang ingin diperjuangkan melalui partai yang dibentuknya. Munculnya banyak partai politik dengan segmen dan ideologi yang beragam membuktikan bahwa rakyat Indonnesia sebenarnya tidak buta politik. Meskipun sistem pemilunya yang diatur dalam UU No. 3 Tahun 1999 tentang Pemilu masih proporsional tanpa menyertakan nama calegnya dalam kartu suara, tetapi Pemilu pada masa reformasi menjadi ajang kompetisi yang cukup sehat bagi para kontestan Pemilu.

Namun demikian, Pemilu 1999 tidak luput dari bebagai bentuk pelanggaran. Panwaslu adalah institusi yang dibentuk tidak hanya melakukan pengawasan terhadap semua proses Pemilu, tetapi juga menyelesaikan terjadinya persengketaan Pemilu, termasuk menyelesaikan penyimpangan-penyimpangan Pemilu serta meneruskan pelanggaran Pemilu ke institusi Penegak Hukum.

Menurut data dari Panwaslu, terdapat berbagai jenis penyimpangan dalam Pemilu 1999. Penyimpangan administratif ada 61394 perkara yang diselesaikan, 3 perkara dilimpahkan kepada polisi, 1 perkara ke pengadilan. Penyimpangan tata cara penyelenggaraan Pemilu ada 1785 perkara yang telah diselesaikan, 12 perkara dilimpahkan kepada Polisi. Penyimpangan berupa tindak Pidana Pemilu ada 347 perkara yang telah diselesaikan, 236 di limpahkan kepada Polisi, dan 24 perkara ke Pengadilan. Penyimpangan yang berupa Money Politic ada 122 perkara yang telah diselesaikan, 18 perkara dilimpahkan kepada Polisi. Penyimpangan yang berkaitan dengan kenetralan birokrasi dan pejabat pemerintah ada 234 perkara yang telah diselesaikan, 1 perkara dilimpahkan kepada Polisi dan 1 perkara ke Pengadilan ${ }^{30}$

Kasus pelanggaran tindak Pidana Pemilu yang menonjol pada Pemilu 1999 adalah kekerasan terhadap partai politik yang dilakukan oleh massa pendukung partai lain, seperti pencabutan, pengrusakan dan pembakaran atribut partai, pengrusakan kantor partai, pembakaran panggung kampanye

"Mohammad AS Hikam "Pemilihan Umum dan Legitimasi Politik" dalam Syamsudin Haris (Ed), Menggugat Pemilihan Umum Orde Baru, (Yayasan Obor Indonesia, Jakarta, 1998), him. 55

${ }^{30}$ Data dari Panwaslu tentang jumlah penyimpangan dalam Pemilu 1999 di seluruh Indonesia, dikutip dari Pertanggungjawaban Panwaslu Pusat Tahun 1999, hlm. 62 
partai dan penghina aktivis atau caleg partai. Hal ini merupakan konsekwensi dari sistem proporsional yang lebih mengedepankan atribut partai seperti tanda gambar dan noror urut partai. ${ }^{31}$ Selain itu, Pemilu 1999 adalah Pemilu dengan sistem Multi Partai yang pertama kali semenjak lengsernya Orde baru, sehingga banyaknya partai politik peserta Pemilu pada Pemilu 1999 sangat potensial menimbulkan gesekan-gesekan yang dapat menimbulkan kekerasan politik

Dari segi kelembagaan, pelaksanaan Pemilu 1999 mengawali sebuah Pemilu yang mendekati demokratis. Ada Komisi Pemilihan Umum yang dibentuk berdasarkan Keputusan Presiden dan di dalamnya merepresentasikan golongan pemerintah dan partai politik. Ini mirip dengan Pemilu 1955. Meskipun demikian, KPU pada Pemilu 1999 dalam perjalannya ternyata menunjukkan contoh yang tidak demokratis, misalnya, ada anggota KPU dari suatu partai politik yang terlibat tender pengadaan logistik dan pertentangan diantara anggota KPU yang terdiri dari berbagai unsur itu, yang kemudian menyebabkan anggota KPU seperti.Prof. Dr. H Harun Al-Rasyid dari Partai yang berbasis pada Islam, memilih keluar dari keanggotaannya di KPU.

Pemilu 1999 selain diawasi oleh Panwaslu juga di awasi lembaga pemantau Pemilu yang non partisan. Hal itu memang dibolehkan dalam UU No 3 tahun 1999. Lembaga Pemantau Pemilu ini dapat berasal dari dalam negeri, mauppun dari luar negeri. Pemantau dari dalam negeri diantaranya dalah KIPP; Forum Rektor, JPPR, JAMPPI,dan lain sebagainya, sedangkan dari luar negeri diantaranya adalah dari Carter Centre, sebuah lembaga yang diketuai oleh Jimmy Carter, mantan Presiden Amerika Serikat. Lembaga Pemantau Pemilu ini dalam Pemilu orde baru sangat mustahil. ${ }^{32}$

Pada Pemilu 2004 secara yuridis mendapatkan penguatan secara konstitusional, sebagaimana ditegaskan dalam Pasal 22E UUD 1945 setelah perubahan. Pemilu 2004 segi kelembagaan pemilu juga ada perubahan. KPU yang pada Tahun 1999 hanya mendapatkan legitimasi dari Keputusan Presiden sebagai dasar pembentukannya, pada Tahun 2004 KPU dikuatkan melalui Konstitusi, yaitu Pasal 22E ayat (5). Komposisi KPU tidak lagi seperti Pemilu 1999. KPU berdasarkan UU No. 12 Tahun 2003 tidak lagi menyertakan wakil-wakil dari partai politik dan pemerintah. Selain itu, KPU memiliki kewenangan yang sangat besar, baik kewenangan menyiapkan dan melaksanakan Pemilu dari segi prosedur, KPU juga harus menyediakan logistik Pemilu. Kewenangan yang besar itu sebenarnya dalam prakteknya dapat berakibat pada terganggunya kinerja KPU. Mestinya hal-hal yang dapat didelegasikan kepada KPU Provinsi, dimungkinkan melalui UU seperti pengadaan logistik Pemilu. Selain itu, sistem Pemilu pada tahun 2004 yang menganut proporsional terbuka masih membingungkan pemilih. Ada dugaan bahwa banyaknya surat yang tidak sah, kemungkinan terjadi karena pemilih masih bingung dengan cara

${ }^{31} / \mathrm{bid}, \mathrm{hlm} 63$

${ }_{32}$ Pada masa orde baru, keberadaan pemantau Pemilu diluar pemantau pemilu resmi dari pemerintah, dianggap pemantau yang illegal. Contohnya adalah KIPP, sebuah organisasi independen pemantau pemilu yang pada waktu Pemilu terakhir pada masa Orde Baru tahun 1997 dianggap inkonstitusional oleh penguasa Orde Baru. Beberapa aktivis KIPP bahkan sempat mendapat perlakuan repressif berupa teror dan kekerasan. 
pemilihan yang berlaku, meskipun jauh-jauh hari sudah ada sosialisasi melalui berbagai media.

Kemudian sistem kepartaian yang ada memang menawarkan banyak pilihan pada rakyat dan pada Pemilu 2004 ini rakyat cukup kritis dalam menjatuhkan pilihannya. Mereka tidak lagi mau terjebak pada pilihan sebelumnya. Dari segi kontestasi, Pemilu 2004 ini tidak jauh berbeda dengan Pemilu 1999. Artinya, banyaknya partai politik yang menjadi kontestan Pemilu menandakan adanya iklim yang baik bagi tumbuhnya demokrasi.

Meskipun Pemilu 2004 diwarnai oleh berbagai kerumitan, tetapi secara umum sistem Pemilu 2004 lebih baik dibandingkan Pemilu sebelumnya. Pemilih dapat menentukan sendiri pilihannya, baik pilihan partainya maupun pilihan wakil-wakilnya. Sistem pemilihan yang seperti itu dapat merekatkan hubungan antara si wakil dan yang diwakilinya. Terlepas dari tidak dikenalnya caleg-caleg dari partai, sistem pemilihan dengan memilih partai dan calegnya dapat menciptakan kontrol yang kuat dari rakyat terhadap wakil-wakilnya di lembaga legislatif. ${ }^{33}$

Selain pemilu legislatif, pada tahun 2004 ini juga dilaksanakan pemilu presiden secara langsung, yang berlangsung dua putaran. Putaran pertama diikuti oleh 5 pasangan calon Presiden dan Wakil Presiden dan putaran kedua diikuti oleh dua pasangan calon Presiden dan Wakil Presiden. Meskipun berbagai kecurangan juga mewarnai pemilu presiden, namun pemilu presiden kali ini dinilai berjalan dengan cukup demokratis.
Tetapi satu hal yang juga tidak boleh dilupakan pada pemilu presiden kali ini adalah jumlah golput yang meningkat. Adanya golput (golongan putih) ini bisa mengurangi legitimasi pasangan Presiden dan Wakil Presiden terpilih sehingga agenda pemilu ke depan harus ada upaya untuk meminimalisir jumlah golput.

\section{d. Pelanggaran Pemilu sebagai Ancaman Demokrasi}

Pemilu tidak dapat dihindarkan dari berbagai pelanggaran. Jika pelanggaran Pemilu makin banyak dan tidak ditangani sesuai dengan hukum dan prosedur yang berlaku, maka hal itu akan berpengaruh terhadap upaya untuk mewujudkan Pemilu yang benar-benar demokratis. Salah satu indikator pemilu yang demokratis adalah minimnya jumlah pelanggaran Pemilu dan penanganan pelanggaran pemilu secara konsisten sesuai hukum pemilu yang berlaku. Pelanggaran Pemilu selalu nampak dalam UU Pemilu, termasuk dalam dalam UU No. 12 Tahun 2003, yang mengkategorikan pelanggaran administrasi dan pelanggaran pidana. Berikut ini berbagai bentuk pelanggaran Pemilu menurut UU No 12 Tahun 2003:

1. Pelanggaran Administratif antara lain :

a) Mencuri start kampanye Pemilu, membawa anak balita, anak dibawah umur untuk kampanye .

b) Surat suara tidak memuat Nomor dan Tanda Gambar Peserta Pemilu, baik partai politik maupun perseorangan

c) Mencoblos lebih dari satu tanda

${ }^{33}$ Dahlan Thaib, Evaluasi Pemilu di Indonesia, dan Pemilu Ideal Indonesia, tulisan untuk masukan di Komisi Konstitusi", 2004 
gambar peserta Pemilu

d) Petugas tidak memberikan bantuan pada pemilih tunanetra, tuna daksa atau yang mempunyai halangan fisik lain sesuia dengan keinginannya

e) Pemberian suara dilakukan di tempat selain TPS, kecuali bagi yang sakit di rumah sakit

f) Pembuatan berita acara tidak ditanda tangani oleh ketua KPPS dan minimal 2 anggota KPPS

g) Surat suara yang rusak tidak mendapatkan ganti dari KPPS

h) Surat suara yang tidak sah, dianggap sah (Pasal 93 U No 12 tahun 2003)

i) Saksi peserta Pemilu tidak membawa surat mandat dari peserta Pemilu

j) Penghitungan suara dilakukan dengan cara yang tidak memungkinkan saksi peserta pemilu, Pengawas Pemilu, Pemantau Pemilu dan warga masyarakat, tidak ikut menyaksikan penghitungan suara

k) Keberatan saksi peserta pemilu atau warga masyarakat tidak ditanggapi

Untuk pelanggaran admintrasi tersebut, Panwaslu yang berwenang mengawasi setiap tahapan pemilu, wajib meneruskan kepada KPU dan selanjutnya, KPU yang akan menyelesaikan pelanggaran administrasi tersebut.

2. Pelanggaran Pidana Pemilu, antara lain :

a) Memalsukan surat yang dibutuhkan untuk keperluan Pemilu, Sesuai dengan Pasal 137 ayat (3), contoh: memalsikan surat suara, memalsukan surat keterangan pindah tempat memilih

b) Sengaja mengunakan atau menyuruh orang lain menggunakan surat palsu sebagai surat sah, sebagaimana diatur dalam asal 134 ayat (4), seperti Pemalsuan ljazah atau KTP pendukung calon angota DPD

c) Menggunakan kekerasan untuk menghalangi seseorang yang akan melakukan pemungutan suara (Pasal 139 ayat (1)

d) Memberikan money politic (Pasal 139 ayat (2)

e) Sengaja Mengatasnamakan orang lain untuk melakukan pemungutan suara (Pasal 139 ayat (3)

f) Sengaja melakukan pencoblosan lebih dari satu kali (Pasal 139 ayat (4)

g) Sengaja menggagalkan Pemungutan suara (Pasal 139 ayat (5)

h) Seorang majikan/atasan yang sengaja tidak memberikan kesempatan kepada pekerjanya untuk memberikan suaranya (Pasal 139 ayat (6)

i) Setiap orang yang sengaja mendampingi pemilih selain yang diatur dalam Pasal 185 ayat (1)

j) Membantu pemilih sengaja memberitahukan pilihan si pemilih kepada orang lain

k) Sengaja melakukan perbuatan yang menyebabkan suara seorang pemilih menjadi tidak berharga dengan cara misalnya merusak surat suara (Pasal 140 ayat (1)

1) Setiap orang yang karena kelalaiannya menyebabkan rusak atau hilangnya hasil pemungutan suara yang telah disegel (Pasal 140 ayat (3)

m) Sengaja mengubah hasil penghitungan suara dan/atau berita acara dan sertifikat hasil penghitungan suara (asal 140 ayat (4). 
Bentuk-bentuk pelanggaran yang begitu konkrit diatur dalam UU No 12 tahun 2003 ini harus ditegakkan. Oleh karena itu, institusi yang diberi tanggungjawab untuk menangani pelanggaran harus mempunyai komitmen untuk melakukan penegakan hukum agar Pemilu yang demokratis benarbenar dapat diwujudkan.

Pelanggaran pidana pemilu yang juga merupakan kejahatan Pemilu tersebut oleh Panwaslu, diteruskan kepada aparat penyidik dan selanjutnya diteruskan pada pengadilan untuk diproses secara hukum, sesuai dengan hukum yang berlaku. Betatapun Pemilu berjalan lancar, jika tidak ada law enforcement terhadap electoral law, Pemilu tidak akan mempunyai arti demokratis. UU No. 12 tahun 2003 sudah cukup mengatur mengeni bentukbentuk pelanggaran Pemilu, tetapi sejauh ini kita masih bertanya sejauhmana elemen-elemen yang terlibat dalam Organisasi Pemilu mempunyai komitmen untuk benar-benar melakukan penegakan Hukum Pemilu. Sebab, Pemilu tahun 2004 juga tidak terlepas dari berbagai bentuk pelanggaran, baik yang berkategori pelanggaran administrasi maupun pidana.

\section{Simpulan}

Meskipun secara garis besar Pemilu 1955 berjalan dengan baik, tetapi juga tidak terlepas dari adanya tindakan yang kurang demokratis yang dilakukan oleh partai politik tertentu melalui oknum-oknumnya. Namun demikian, sebagai langkah awal untuk membentuk pemerintahan yang demokratis, Pemilu 1955 menjadi preseden yang baik bagi tumbuhnya semangat berdemokrasi untuk Indonesia.
Berbeda dengan Pemilu 1955, pemilupemilu Orde Baru dilaksanakan melalui sebuah proses yang tersentralisasi pada tangan-tangan birokrasi yang mana tangan-tangan tersebut tidak hanya mengatur hampir seluruh proses Pemilu, tetapi juga berkepentingan untuk merekayasa kemenangan "partai milik pemerintah". Kompetisi ditekan sedemikan rupa dan keragaman pandangan tidak memperoleh empat secara memadai. Pemilu Ordé Baru tidak ditujukan untuk mengubah sistem politik, melainkan hanya untuk meneguhkan dan mengabsahkan sistem yang berlaku.

Meskipun diwarnai oleh berbagai kerumitan, tetapi secara umum sistem Pemilu 2004 lebih baik dibandingkan Pemilu sebelumnya. Pemilih dapat menentukan sendiri pilihannya, baik pilihan partainya maupun pilihan wakil-wakilnya. Sistem pemilihan yang seperti itu dapat merekatkan hubungan antara si wakil dan yang diwakilinya.

\section{Daftar Pustaka.}

Asshiddiqie, Jimly, Konstitusi dan Konstitusionalime Indonesia, diterbitkan oleh Mahkamah Konstitusi RI dan Pusat Studi Hukum Tata Negara Universitas indonesia, Jakarta, 2004.

Fatah, Eep Saifullah, Pemilu dan Demokratisasi, Evaluasi terhadap Pemilu-Pemilu Orde Baru, Laboratorium FISIP UI dan Mizan, Jakarta - Bandung, 1997

Feith, Herbert, Pemilihan Umum 1955 di Indonesia, KPG, Jakarta, 1999.

Gaffar, Afan, Politik Indonesia; Transisi Menuju Demokrasi, Cet. Kedua, Pustaka Pelajar, 2000. 
Sri Hastuti P. Pengalaman Indonesia Menuju Demokrasi ...

Haris, Syamsudin dan Reza Sihbudi (ed), Menelaah Kembali Format Politik Orde Baru, Gramedia, Jakarta, 1995

Haris, Syamsudin (ed), Menggugat Pemilihan Umum Orde Baru, Yayasan Obor Indonesia, Jakarta, 1998

Held, David, Demokrasi dan Tatanan Global, Dari Negara Modern hingga Pemerintahan Kosmopolitan, Penerjemah Damanhuri, Pustaka Pelajar, Yogyakarta, 2004

Koesnardi, Moh. dan Hamaily lbrahim, Pemgantar Hukum Tata Negara Indonesia, Pusat Studi Hukum Tata Negara Universitas Indonesia, Jakarta, 1988.

MD, Moh. Mahfud, Demokrasi dan Konstitusi di Indonesia, Liberty, Yogyakarta, 1993 $\rightarrow$ Politik Hukum di Indonesia, LP3ES, Jakarta, 1998

Nasution, Adnan Buyung, Aspirasi Pemerintahan Konstitusional di Indonesia: Studi Sosio Legal atas Konstituante 1956-1959, Cet. Kedua, Grafiti, Jakarta, 2001

Samego, Indria, dkk (ed) Dinamika Kedaulatan Rakyat; Dilema-Dilema dalam Pemilu, Sistem Kepartaian dan Lembaga Perwakilan, Pustaka Cidesindo, Jakarta, 1997.

Sorensen, Georg, Demokrasi dan Demokratisasi: Proses dan Prospek dalam Dunia Yang Sedang Berubah, penerjemah I. Made Krisna, Pustaka Pelajar, Yogjakarta, 2003.

Strong, C.F., Konstitusi-Konstitusi Politik Modern, Kajian tentang Sejarah dan BentukBentuk Konstitusi Dunia, diterjemahkan oleh SPA Teamwork, Penerbit Nuansa dan Nusamedia, Bandung, 2004

Thaib, Dahlan ," Evaluasi Pemilu di Indonesia, dan Pemilu Ideal Indonesia", tulisan untuk masukan di Komisi Konstitusi", 2004.

Panwaslu Pusat, Pengawasan Pemilihan Umum 1999; Pertanggungjawaban Panwaslu Pusat Tahun 1999, Panwaslu Pusat, Jakarta, 1999

Republik Indonesia, UU No 7 Tahun 1953 tentang Pemilihan Umum

, UU No 15 Tahun 1969 tentang Pemilihan Umum untuk Anggauta Badan Permusywaratan/Lembaga Perwakilan

, UU No 4 Tahun 1975 tentang Perubahan atas UU No 15 Tahun 1969 tentang Pemilihan Umum untuk Anggauta Badan Permusywaratan/ Lembaga Perwakilan

UU No 2 Tahun 1980 tentang Perubahan atas UU No 15 Tahun 1969 sebagaimana telah di rubah dengan UU No 4 Tahun 1975

, UU No. 1 Tahun 1985 tentang Pemilihan anggota MPR, DPR dan DPRD

, UU No. 3 Tahun 1999 tentang Pemilihan Umum

, UU No 12 tahun 2004 tentang Pemilihan Umum untuk anggota DPR, DPD dan DPRD

UU No.23 Tahun 2003 tentang Pemilihan Umum presiden dan Wakil Presiden 